University of Nebraska - Lincoln

DigitalCommons@University of Nebraska - Lincoln

5-1987

\title{
Effects of Planting Date on Development of Net Blotch Epidemics in Winter Barley in Pennsylvania
}

Leslie M. Delserone

University of Nebraska-Lincoln, Idelserone2@unl.edu

H. Cole Jr.

Pennsylvania State University

Follow this and additional works at: https://digitalcommons.unl.edu/libraryscience

Part of the Agricultural Science Commons, Agriculture Commons, Agronomy and Crop Sciences Commons, Horticulture Commons, Library and Information Science Commons, and the Plant Pathology Commons

Delserone, Leslie M. and Cole, H. Jr., "Effects of Planting Date on Development of Net Blotch Epidemics in Winter Barley in Pennsylvania" (1987). Faculty Publications, UNL Libraries. 246.

https://digitalcommons.unl.edu/libraryscience/246

This Article is brought to you for free and open access by the Libraries at University of Nebraska-Lincoln at DigitalCommons@University of Nebraska - Lincoln. It has been accepted for inclusion in Faculty Publications, UNL Libraries by an authorized administrator of DigitalCommons@University of Nebraska - Lincoln. 


\title{
Effects of Planting Date on Development of Net Blotch Epidemics in Winter Barley in Pennsylvania
}

\author{
L. M. DELSERONE, Graduate Research Assistant, and H. COLE, JR., Professor of Plant Pathology, The \\ Pennsylvania State University, University Park 16802
}

\begin{abstract}
Delserone, L. M., and Cole, H., Jr. 1987. Effects of planting date on development of net blotch epidemics in winter barley in Pennsylvania. Plant Disease 71:438-441.

The influence of planting date on fall and spring net blotch epidemics (caused by Pyrenophora teres) was evaluated with the winter barley cultivar Pennrad. Experiments were conducted in Centre County, Pennsylvania, in 1982 and 1983 and in Lancaster County, Pennsylvania, in 1983. The three planting dates evaluated corresponded to the recommended date as well as dates $1 \mathrm{wk}$ earlier and later than recommended for each specific location. Planting date had a significant influence on fall net blotch epidemics, with the greatest and least disease severities observed in the earliest and latest plantings, respectively. When spring environmental conditions were warm and humid, previous differences in disease severities attributable to date were eliminated. With less favorable spring weather, planting date had a significant influence on spring net blotch severities. Planting date also affected yield components, specifically the number of seeds per head and the thousand-kernel weight and the calculated yield. The greatest values for these factors generally were observed for the latest planting. Applications of fungicides during the spring epidemics generally resulted in a significant decrease in disease severity and an increase in one or more yield components. Planting in mid- to late September at either location resulted in the lowest net blotch severities and greatest yields.
\end{abstract}

Net blotch of barley caused by Pyrenophora teres Drechs. (anamorph: Drechslera teres (Sacc.) Shoem., syn. Helminthosporium teres Sacc.) has increased in incidence and severity in the United States and Canada in recent years (10). This disease (among other factors) has caused barley production in Pennsylvania to decline from 60,750 ha in 1975 to 30,352 ha in $1982(1)$.

Yield loss attributed to net blotch is not documented. However, sprays of maneb applied at regular intervals from the three-leaf stage through flowering increased yields by $65 \%$ (9), and one spray of propiconazole applied at flag leaf emergence increased yields 17-23\% (3).

Planting date may affect the development of a net blotch epidemic. Some

Portion of a thesis submitted by the first author to The Pennsylvania State University for the M.S. degree. Present address of first author: Department of Plant Pathology, Cornell University, Ithaca, NY 14853.

Contribution 1536, Department of Plant Pathology, Pennsylvania State Agricultural Experiment Station. Authorized for publication as Journal Series Paper 7299.

Accepted for publication 22 October 1986.

The publication costs of this article were defrayed in part by page charge payment. This article must therefore be hereby marked "advertisement" in accordance with 18 U.S.C. $\$ 1734$ solely to indicate this fact.

This article is in the public domain and not copyrightable. It may be freely reprinted with customary crediting of the source. The American Phytopathological Society, 1987.
Pennsylvania growers plant barley before the recommended dates to ensure winter survival. Preliminary studies indicated greater disease levels in earlier plantings (J. A. Frank, unpublished). The objective of this study was to determine the effect of planting date on the development of fall and spring net blotch epidemics and on yield. These data then could be used for developing planting date recommendations to minimize the severity of net blotch in Pennsylvania.

\section{MATERIALS AND METHODS}

Treatments and design. Field experiments were conducted on The Pennsylvania State University Research Farms in Centre and Lancaster counties. Planting dates, tillage, and rotation conditions are listed in Table 1. In the Centre County study of 1982-1983 (CC 1982/83), the earliest planting date was that recommended for barley planting in central Pennsylvania, and in 1983-1984 (CC 1983/84), the earliest planting date was $1 \mathrm{wk}$ earlier than recommended (2). In southeastern Pennsylvania, winter weather is milder than in the central part of the state, so that the normal planting date is about 2 wk later than that for central Pennsylvania. In the Lancaster County 1983-1984 study (LC 1983/84), the first planting date was about 1 wk earlier than that recommended for the region. A planned third planting could not be made in the LC study because of unfavorable weather conditions.

The winter barley (Hordeum vulgare L. emend. Bowden) cultivar Pennrad was planted in all experiments. Pennrad is resistant to the major foliar diseases of barley in Pennsylvania (leaf rust and powdery mildew) but is susceptible to net blotch (2). The cultivar also has good winterhardiness and is recommended for planting throughout Pennsylvania (2).

A planting date test block consisted of two drill strips, each $2.1 \mathrm{~m}$ wide and $86 \mathrm{~m}$ long, with seven rows per strip. Each drill strip was divided into eight plots, providing 16 plots per planting date block, each $2.1 \times 10.7 \mathrm{~m}$. These plots served as replicates nested within the planting date block. In CC 1982/83, both drill strips were sown with untreated seed at the rate of $161.3 \mathrm{~kg} / \mathrm{ha}$. Because results from CC $1982 / 83$ indicated that spring fungicide spray alone had no effect on spring epidemics, we used a fungicidal seed treatment in 1983/1984 to evaluate the effect of seed-transmitted P. teres on the development of fall epidemics. In $\mathrm{CC}$ 1983/84 and LC 1983/84, one drill strip per block was planted with untreated seed and the other with treated seed. The seed treatment consisted of a mixture of imazalil ( $5.8 \%$ a.i.) applied at the rate of 1 $\mathrm{ml} / \mathrm{kg}$ of seed and triadimenol $(0.15 \mathrm{~kg}$ a.i./ L) applied at the rate of $0.9 \mathrm{ml} / \mathrm{kg}$ of seed. The seeding rate in the $1983 / 1984$ studies was reduced to $134.4 \mathrm{~kg} / \mathrm{ha}$, because winter-kill was not extensive enough to warrant the seeding rate used in $1982 / 1983$. In all studies, the drill

Table 1. Planting dates and cultural factors of the date-of-planting studies

\begin{tabular}{|c|c|c|c|}
\hline Site ${ }^{a}$ and year & Planting dates & Tillage & Previous crop \\
\hline CC $1982 / 83$ & $\begin{array}{l}14 \text { Sept. } \\
20 \text { Sept. } \\
27 \text { Sept. }\end{array}$ & Chisel-plow, disc & Oats \\
\hline CC $1983 / 84$ & $\begin{array}{r}6 \text { Sept. } \\
15 \text { Sept. } \\
29 \text { Sept. }\end{array}$ & Chisel-plow, disc & Oats \\
\hline LC $1983 / 84$ & $\begin{array}{l}16 \text { Sept. } \\
30 \text { Sept. }\end{array}$ & Moldboard-plow, disc & Corn \\
\hline
\end{tabular}

${ }^{\mathrm{a}} \mathrm{CC}=$ Centre and $\mathrm{LC}=$ Lancaster counties of Pennsylvania. 
strips within a block were separated from each other by a $12-\mathrm{m}$-wide winter wheat buffer to reduce interplot interference. A 30-m-wide buffer zone was placed between blocks to reduce interblock interference. These zones were planted with oats in the spring. Seeding depth, row spacing, fall and spring fertilization, and spring herbicide rates used in the studies were those recommended for Pennsylvania (2).

To achieve different levels of net blotch, spring fungicide treatments were applied. In CC 1982/83, a subplot $1 \times 3 \mathrm{~m}$ was delimited approximately in the center of each plot. Eight of these subplots were selected randomly per block and were sprayed with mancozeb $(80 \%$ a.i. WP) at the rate of $1.79 \mathrm{~kg}$ a.i./ha. The sprays were applied when plants were at growth stages (GS) 5 and 7 (Feekes scale) (5). The remaining eight unsprayed subplots per block served as controls. In CC 1983/84 and LC 1983/84, all barley plots planted with treated seed were sprayed once with propiconazole (3.6EC) at the rate of $0.12 \mathrm{~kg}$ a.i./ha. (Propiconazole was not available for the $1982 / 1983$ studies.) In CC 1983/84, the spray was applied when barley in the first, second, and third blocks was at GS 9,8 , and 6, respectively. In LC 1983/84, the spray was applied when barley in the first and second blocks was at GS 7 and 6, respectively. No additional sprays were made, because disease levels were low. Plots planted with untreated seed were not sprayed.

Disease assessments. Fall net blotch assessments were made after periods of weather conducive to infection by $P$. teres. At each assessment, four groups of plants, each one linear meter of row, were dug at random from each block and taken to the laboratory. Twenty-five primary tillers were evaluated per group of plants for net blotch severity, for a total of 100 tillers per planting date block. Disease severity was assessed by estimating the percentage of infected leaf tissue. Both necrotic lesions and associated chlorosis were evaluated as affected tissue. ( $P$. teres secretes toxins that cause chlorosis around infection sites [11].) Each of four leaves on the primary tiller was evaluated separately. The severities on individual leaves were totaled and divided by the number of leaves assessed to determine the mean disease severity per tiller. The mean disease severity per tiller represented the mean severity of the 100 tillers evaluated.

All disease assessments in the spring were conducted in the field. At each assessment, 25 tillers were evaluated in each of the sprayed and unsprayed plots as described. Four disease assessments were conducted; however, not all assessments are presented in the tables. The additional assessments were used to calculate area under the disease progress curve (AUDPC) and apparent infection rates $(r$ values) $(8,12)$. In some instances, four assessments could not be made and disease parameters were not calculated.

Yield determination. After ripening, one linear meter of row was cut at random and bundled from each sprayed and unsprayed plot in each block. Several yield components were measured, including the number of tillers, number of heads, number of seeds per head, and thousand-kernel weight (tkw). Seed weight per meter of row was converted to kilograms per hectare (calculated yield).

Analyses. The AUDPC and $r$ values for spring epidemics were calculated for each date $(8,12)$. Fall disease data in CC $1982 / 83$ were analyzed using a completely randomized design, with replicates nested in date. Although the 1983/1984 studies involved both seed treatment and fungicide sprays, the fall and spring disease data could be analyzed separately. Fall disease data in CC 1983/84 and LC $1983 / 84$ and all spring disease and yield data were analyzed using a split-block design (fixed effects model), with replicates nested in date. Mean separation was performed using the Waller-Duncan Bayesian $k$-ratio $t$ test $(k=100)$.

\section{RESULTS}

Fall epidemics. The mean disease severities of the fall epidemics are presented in Table 2. Results of the first and last of four assessments conducted in CC 1982/83 and all fall assessments conducted in the $1983 / 1984$ studies are

Table 2. Effects of planting date and fungicidal seed treatment on severity of fall net blotch epidemics in winter barley cultivar Pennrad in Centre and Lancaster counties, Pennsylvania

\begin{tabular}{|c|c|c|c|c|c|c|c|}
\hline \multirow{2}{*}{$\begin{array}{c}\text { Site }{ }^{\mathrm{a}} \text { and } \\
\text { year }\end{array}$} & \multirow{2}{*}{$\begin{array}{l}\text { Assessment } \\
\text { date }\end{array}$} & \multirow{2}{*}{$\begin{array}{l}\text { Planting } \\
\text { date }^{\mathbf{b}}\end{array}$} & \multirow[b]{2}{*}{$\mathbf{G S}^{\mathbf{c}}$} & \multicolumn{2}{|c|}{ Disease severity $(\%)^{d}$} & \multicolumn{2}{|c|}{$\boldsymbol{P}>\boldsymbol{F}$} \\
\hline & & & & $\mathbf{T}^{\mathbf{e}}$ & $N^{e}$ & Date & Fungicide \\
\hline \multirow[t]{3}{*}{ CC $1982 / 83$} & 18 Oct. & 1 & 3 & $\cdots$ & 2.2 & & \\
\hline & & 2 & 3 & $\cdots$ & 0.5 & & \\
\hline & & 3 & 2 & $\ldots$ & 0.0 & 0.0751 & $\ldots$ \\
\hline \multirow[t]{4}{*}{ Bayes LSD: ${ }^{f}$} & & \multicolumn{6}{|c|}{2.09} \\
\hline & 9 Dec. & 1 & 3 & $\cdots$ & 41.4 & & \\
\hline & & 2 & 3 & $\ldots$ & 38.7 & & \\
\hline & & 3 & 3 & $\ldots$ & 15.0 & 0.0001 & $\ldots$ \\
\hline Bayes LSD: & & \multicolumn{6}{|c|}{5.97} \\
\hline \multirow[t]{3}{*}{ CC $1983 / 84$} & 22 Oct. & 1 & 2 & 29.2 & 31.8 & & \\
\hline & & 2 & 2 & 3.9 & 11.9 & & \\
\hline & & 3 & 2 & 0.0 & 0.0 & 0.0030 & 0.0000 \\
\hline \multirow[t]{4}{*}{ Bayes LSD: } & & \multicolumn{6}{|c|}{9.10} \\
\hline & 2 Dec. & 1 & 3 & 57.6 & 57.2 & & \\
\hline & & 2 & 3 & 49.6 & 42.6 & & \\
\hline & & 3 & 2 & 0.4 & 0.8 & 0.0004 & 0.0191 \\
\hline \multicolumn{2}{|l|}{ Bayes LSD: } & \multicolumn{6}{|c|}{9.82} \\
\hline \multirow[t]{4}{*}{ LC $1983 / 84$} & 7 Nov. & 1 & 3 & 7.1 & 7.2 & & \\
\hline & & 2 & 2 & 0.2 & 1.4 & 0.0295 & 0.6843 \\
\hline & 7 Dec. & 1 & 3 & 5.2 & 25.2 & & \\
\hline & & 2 & 3 & 2.0 & 13.0 & 0.0189 & 0.0612 \\
\hline
\end{tabular}

${ }^{\mathrm{a}} \mathrm{CC}=$ Centre and $\mathrm{LC}=$ Lancaster counties.

${ }^{\mathrm{b}}$ Planting dates 1, 2, and 3 in CC are 14, 20, and 27 September 1982 and 6, 15, and 29 September 1983, respectively. Dates in LC are 16 and 30 September 1983.

${ }^{c}$ Growth stage according to Feekes scale (5).

${ }^{\mathrm{d}}$ Calculated by totaling severities of individual leaves of tiller and dividing by number of leaves assessed (mean of 25 tillers per plot).

${ }^{\mathrm{e}} \mathrm{T}=$ mixture of imazalil and triadimenol as seed treatment; NT = not treated.

${ }^{\mathrm{f}}$ Means separation for date, Waller-Duncan Bayesian $k$-ratio $t$ test $(k=100)$. Where only two dates were evaluated, significance is based on analysis of variance $(P=0.05)$. 
in both treated and control plots ranged from 0.002 to 0.005 . Differences in AUDPC attributable to planting date epidemic in the first planting (control plots) had a greater AUDPC than that in the third $(1,100.8$ vs. 774.3 , respectively). The fungicide treatment had a significant effect on AUDPC in all plantings. The AUDPC in treated vs. control plots in the first, second, and third plantings were, respectively, 846.4 vs. $1,100.8,730.4$ vs. $1,051.0$, and 341.4 vs. 774.3. The AUDPCs for LC 1983/ 84 were affected by planting date and fungicide treatment. The epidemic in the first planting (control plots) had the greatest AUDPC (548.8 vs. 419.9). The AUDPC for treated vs. control plots in the first and second plantings were, respectively, 344.5 vs. 548.8 and 227.4 vs. 419.9 .

Yield. The components of yield and calculated yields for all studies are presented in Table 4. In CC 1982/83, there were no differences attributable to planting date in the control plots; mancozeb treatments increased the calculated yield.

In CC 1983/84, planting date affected the number of seeds per head and tkw of were observed in CC $1983 / 84$. The

control plots. The greatest values for these factors were calculated for the third planting. In LC $1983 / 84$, planting date also affected the number of seeds per head, tkw, and the calculated yield of control plots, but the greatest values were observed in the second planting. The propiconazole treatment significantly increased the tkw in both plantings.

\section{DISCUSSION}

In all studies, the highest net blotch severities of the fall were recorded in the earliest planting. These plants were exposed to inoculum and favorable environmental conditions for a longer period of time than later-sown barley.

The efficacy of the fungicidal seed treatment was evaluated at two locations with different inoculum levels. The seed treatment had some effect on fall net blotch severity in CC 1983/84. Treated seed was planted in a field in which barley had been the previous crop and where infested debris was not plowed under to reduce the initial inoculum level (7). The information from CC 1983/84 does not support the observation that seed treatments for net blotch control in the

Table 3. Effects of planting date and fungicide sprays on severity of spring net blotch epidemics in winter barley cultivar Pennrad in Centre and Lancaster counties, Pennsylvania

\begin{tabular}{|c|c|c|c|c|c|c|c|}
\hline \multirow{2}{*}{$\begin{array}{l}\text { Site }{ }^{a} \text { and } \\
\text { year }\end{array}$} & \multirow{2}{*}{$\begin{array}{c}\text { Assessment } \\
\text { date }\end{array}$} & \multirow{2}{*}{$\begin{array}{c}\text { Planting } \\
\text { date }^{\mathbf{b}}\end{array}$} & \multirow[b]{2}{*}{$\mathbf{G S}^{\mathbf{c}}$} & \multicolumn{2}{|c|}{ Disease severity (\%) } & \multicolumn{2}{|c|}{$\boldsymbol{P}>\boldsymbol{F}$} \\
\hline & & & & $\mathbf{T}^{\mathbf{e}}$ & $\mathbf{N T}^{\mathbf{e}}$ & Date & Fungicide \\
\hline \multirow[t]{3}{*}{ CC $1982 / 83$} & 26 May & 1 & 10.5 .1 & 5.9 & 8.8 & & \\
\hline & & 2 & 10.5 .1 & 3.6 & 7.3 & & \\
\hline & & 3 & 10.5 & 3.7 & 7.3 & 0.1202 & 0.0039 \\
\hline \multicolumn{2}{|c|}{ Bayes LSD: ${ }^{f}$} & \multicolumn{6}{|c|}{ NS } \\
\hline & \multirow[t]{3}{*}{13 June } & 1 & 11.1 & 29.8 & 36.3 & & \\
\hline & & 2 & 11.1 & 27.0 & 30.7 & & \\
\hline & & 3 & 11.1 & 30.8 & 34.1 & 0.3479 & 0.1623 \\
\hline \multicolumn{2}{|c|}{ Bayes LSD: } & \multicolumn{6}{|c|}{ NS } \\
\hline \multirow[t]{3}{*}{ CC $1983 / 84$} & 25 May & 1 & 10.3 & 6.6 & 7.6 & & \\
\hline & & 2 & 9 & 5.7 & 5.1 & & \\
\hline & & 3 & 8 & 2.1 & 1.0 & 0.0001 & 0.5348 \\
\hline \multicolumn{2}{|l|}{ Bayes LSD: } & \multicolumn{6}{|c|}{1.82} \\
\hline & 1 June & 1 & 10.5 .4 & 8.0 & 21.8 & & \\
\hline & & 2 & 10.5 .4 & 4.9 & 19.9 & & \\
\hline & & 3 & 10.5 .3 & 0.7 & 8.4 & 0.0001 & 0.0001 \\
\hline \multicolumn{2}{|l|}{ Bayes LSD: } & \multicolumn{6}{|c|}{2.61} \\
\hline & 11 June & 1 & 11.2 & 28.9 & 41.0 & & \\
\hline & & 2 & 11.2 & 21.6 & 34.9 & & \\
\hline & & 3 & 11.1 & 7.9 & 25.7 & 0.0001 & 0.0001 \\
\hline \multicolumn{2}{|c|}{ Bayes LSD: } & \multicolumn{6}{|c|}{4.39} \\
\hline \multirow[t]{6}{*}{ LC $1983 / 84$} & 22 May & 1 & 10.5 & 3.0 & 12.1 & & \\
\hline & & 2 & 10.3 & 2.3 & 5.2 & 0.0018 & 0.0002 \\
\hline & 31 May & 1 & 10.5 .4 & 24.2 & 36.8 & & \\
\hline & & 2 & 10.5 & 15.6 & 32.1 & 0.0260 & 0.0001 \\
\hline & 6 June & 1 & 11.1 & 39.2 & 43.1 & & \\
\hline & & 2 & 10.5 .4 & 24.2 & 33.6 & 0.0079 & 0.0025 \\
\hline
\end{tabular}

${ }^{\mathrm{a}} \mathrm{CC}=$ Centre and $\mathrm{LC}=$ Lancaster counties.

${ }^{b}$ Planting dates 1,2, and 3 in CC are 14, 20, and 27 September 1982 and 6, 15, and 29 September 1983, respectively. Dates in LC are 16 and 30 September 1983.

${ }^{c}$ Growth stage according to Feekes scale (5).

${ }^{\mathrm{d}}$ Calculated by totaling severities of individual leaves of tiller and dividing by number of leaves assessed (mean of 25 tillers per plot).

${ }^{\mathrm{C}}$ In CC 1982/83, T = two sprays of mancozeb. In CC 1983/84 and LC 1983/84, T = mixture of imazalil and triadimenol as seed treatment + one spray of propiconazole. NT $=$ not treated.

${ }^{f}$ Means separation for date, Waller-Duncan Bayesian $k$-ratio $t$ test $(k=100)$. Where only two dates were evaluated, significance is based on analysis of variance $(P=0.05)$. fall are ineffective when seedlings are exposed to high inoculum levels in the field (4). Based on these preliminary results, seed treatment with a mixture of imazalil and triadimenol may be useful in preventing the introduction of $P$. teres into plowed fields (6). The initial inoculum level resulting from infested debris should be considered before using these chemicals.

The highest net blotch severities in all studies at the first spring assessment were observed in the earliest planted barley. $P$. teres could overwinter in fall-infected, but later dead, leaf tissue $(7,10)$. The early-sown plants might be expected to have the highest disease severities throughout the spring, given a carryover of inoculum from the fall. In CC 1982/83, there were no differences attributable to date in net blotch severities at either assessment. In the $1983 / 1984$ studies, however, differences were present at the last assessment at both locations. We hypothesize that these discrepancies may be explained in part by differences in the spring environmental conditions of the two years. Both the level of primary inoculum and the number of opportunities for secondary infection affect the severity of epidemics (6). Warm, humid weather in spring 1983 may have allowed more cycles of secondary infection in the second and third plantings, thus eliminating any early advantage these plants may have had. In CC 1983/84, the spring was wet but cold, and secondary cycles of infection may not have occurred as frequently.

Planting barley in mid- to late September reduced disease severity and, in LC $1983 / 84$, also led to an increase in calculated yield. (In CC 1982/83 and CC $1983 / 84$, the last planting had the best yield, but this value proved not to be statistically significant.) Disease control using foliar fungicides mimicked the potential yield gain resulting from later planting. In CC 1982/83, mancozeb sprays increased the calculated yield of the first planting by $21 \%$.

Later planting led to increases in both seed number per head and tkw in the last-sown blocks of CC 1983/84 and LC $1983 / 84$. Infection by $P$. teres is reported to decrease tkw, but there are conflicting reports about the effect of infections on seed number $(3,6)$. Plots treated with the seed treatment/propiconazole combination also reflected an increase in these components. In CC $1983 / 84$, the fungicide increased seed number per head by 11 and $5 \%$ for the first and second plantings, respectively. In LC 1983/84, there was a $16 \%$ increase in tkw in the earliest planting with fungicide treatment. Despite the disease reduction on mancozebtreated plants in CC 1982/83, there were no differences in any of the yield components. Possibly, if mancozeb sprays had been applied throughout the spring, the reduction in net blotch severity would 
Table 4. Effects of planting date and fungicide sprays on the yield of the winter barley cultivar Pennrad in Centre and Lancaster counties, Pennsylvania

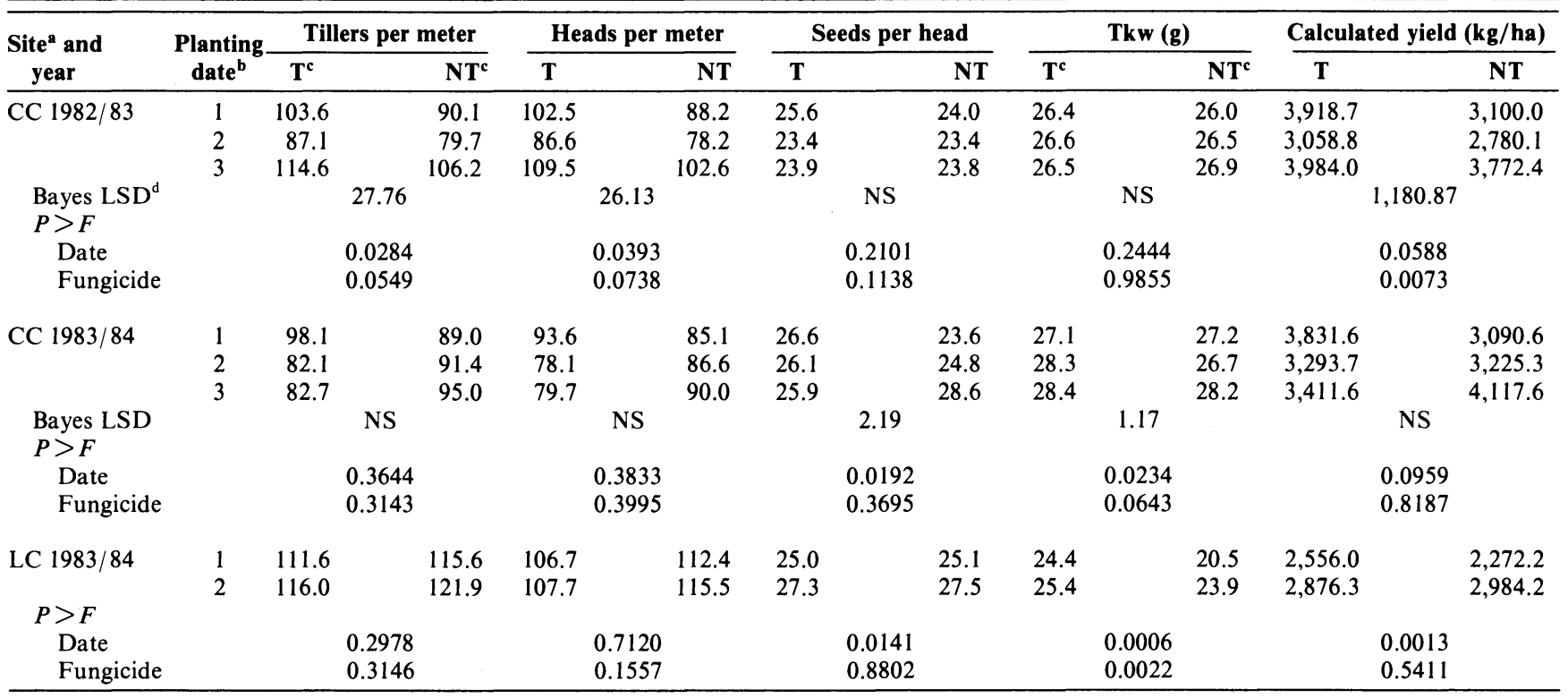

${ }^{\mathrm{a}} \mathrm{CC}=$ Centre and $\mathrm{LC}=$ Lancaster counties.

${ }^{\mathrm{b}}$ Planting dates 1,2 , and 3 in CC are 14,20, and 27 September 1982 and 6, 15, and 29 September 1983, respectively. Dates in LC are 16 and 30 September 1983.

${ }^{\mathrm{c}}$ In CC 1982/83, T = two sprays of mancozeb. In CC 1983/84 and LC 1983/84, T = mixture of imazalil and triadimenol as seed treatment + one spray of propiconazole. NT $=$ not treated.

${ }^{\mathrm{d}}$ Means separation of date, Waller-Duncan Bayesian $k$-ratio $t$ test $(k=100)$. Where only two dates were evaluated, significance is based on analysis of variance $(P=0.05)$.

have led to the increase in tkw reported by other researchers (9).

Planting in mid- to late September in both years and locations of this study significantly reduced net blotch levels and increased calculated yields, tkw, and seed number per head compared with earlier plantings. It is feasible to recommend that growers plant $10-20$ September in central Pennsylvania, as recommended by the Penn State Agronomy Guide (2), for lower net blotch severities. It would be beneficial for growers in southeastern Pennsylvania to plant 20-30 September.

\section{ACKNOWLEDGMENTS}

We thank J. A. Frank, who served as major advisor for this work, L. J. Jordan, G. E. Rebarchak,
J. G. Stover, and J. O. Yocum for excellent technical assistance, and R. R. Hill for statistical advice.

\section{LITERATURE CITED}

1. Anonymous. 1983. Agricultural Statistics. U.S Department of Agriculture, Washington, DC. $558 \mathrm{pp}$.

2. Anonymous. 1983. The Penn State Agronomy Guide, 1983-1984. Penn. State Univ. Ext. Serv. University Park. 89 pp.

3. Jordan, V. W. L. 1981. Aetiology of barley net blotch caused by Pyrenophora teres and some effects on yield. Plant Pathol. 30:77-87.

4. Jordan, V. W. L., and Best, G. R. 1981 Evaluation of fungicide treatments for control of barley net blotch caused by Pyrenophora teres. Pages 249-258 in: Proceedings, 1981 British Crop Protection Conference-Pests and Diseases, Long Ashton Research Station, Bristol, UK.

5. Large, E. C. 1954. Growth stages in cereals: Illustration of Feekes scale. Plant Pathol. 3:128-129.
6. Mathre, D. E., ed. 1982. Compendium of Barley Diseases. American Phytopathological Society, St. Paul, MN. 78 pp.

7. Piening, L. 1968. Development of barley net blotch from infected straw and seed. Can. J. Plant Sci. 48:623-625.

8. Shaner, G., and Finney, R. E. 1977. The effect of nitrogen fertilization on the expression of slow-mildewing resistance. Phytopathology 67:1051-1056.

9. Shipton, W. A. 1966. Effect of net blotch infection of barley on grain yield and quality. Aust. J. Agric. Anim. Husb. 6:437-440.

10. Shipton, W. A., Khan, T. N., and Boyd, W. J. R. 1973. Net blotch of barley. Rev. Plant Pathol. 52:269-290.

11. Smedegard-Petersen, V. 1976. Pathogenesis and Genetics of Net-Spot Blotch and Leaf Stripe of Barley Caused by Pyrenophora teres and $P$. graminea. DSR Forlag, Copenhagen. $176 \mathrm{pp}$.

12. Vanderplank, J. E. 1963. Plant Diseases: Epidemics and Control. Academic Press, New York. 349 pp. 